\title{
O ASCETISMO COMO SINTOMA DA VONTADE DE PODER DOENTE
}

\author{
[THE ASCETISM AS A SYPTHOM OF THE SICK WILL TO POWER]
}

\author{
Junot Cornélio Matos * \\ Universidade Federal de Pernambuco, Brasil \\ Antonio de Odilon Brito ** \\ Universidade Federal de Pernambuco, Brasil
}

\begin{abstract}
Resumo: O presente artigo possui como objetivo argumentar que $\mathrm{o}$ ascetismo em Nietzsche, desenvolvido pelo autor principalmente em sua Genealogia da Moral, pode ser encarado como sendo um sintoma de uma Vontade de Poder enfraquecida. Primeiramente buscar-se-á apresentar uma conceituação do que vem a ser a Vontade de Poder em Nietzsche, bem como argumentar a favor de seu caráter ôntico-ontológico, do qual deriva o segundo conceito trabalhado neste artigo. O segundo passo será dado no sentido de conceituar o que o autor compreende como sendo os ideais ascéticos em relação com a moral escrava. O terceiro e último passo, por fim, consistirá na demonstração de uma relação entre o primeiro conceito e o ascetismo, argumentando ser este um sintoma de uma vida doente. Isto é, se vida e mundo são Vontade de Poder, logo o ascetismo, longe de ser expressão de uma falta daquela, nada mais seria que não um sintoma de uma doença, que consistiria no enfraquecimento da essência do ente humano.
\end{abstract}

Palanras-chave: Vontade de Poder; Ideais ascéticos; Saúde. Doença; Genealogia da Moral
ABSTRACT: The present article has as an objective arguing that asceticism in Nietzsche, developed by the author mainly in his On the Genealogy of Morality, can be faced as a symptom of a weakened Will to Power. Firstly one will seek to present a conceptualization of what is the Will to Power in Nietzsche, as well as arguing in favour of its ontic-ontological character, from which the second concept of this article is derived. The second step will be given in the direction of conceptualizing what the author understands as being the ascetic ideals in relation to the slave morality. The third and last step, lastly, will consist in the demonstration of a relation between the first concept and asceticism, arguing that the later is a symptom of an ill life. That is, if life and world are Will to Powert, hence asceticism, far from being an expression of the lack of the former, would be nothing more than a symptom of a disease, which would consist in the weakening of the essence of the human being. KeYwords: Will to Power; Ascetics Ideals; Health; Disease; Genealogy of Morals

\section{I - INTRODUÇÃo}

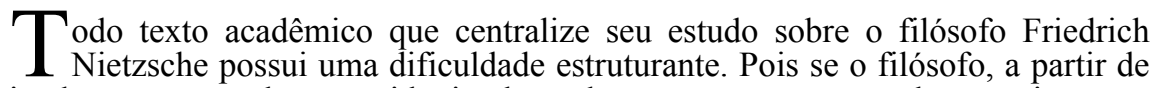
determinado momento de sua vida intelectual, passou a escrever de maneira nãosistemática (reflexo, dentre outras coisas, de sua visão sobre a metafísica), como é possível que se decida escrever um texto essencialmente sistemático a partir desse autor?

* Professor do Departamento de Filosofia da Universidade Federal de Pernambuco (UFPE); Doutor em Educação pela Universidade Estadual de Campinas (UNICAMP); Mestre em Filosofia pela Universidade Federal de Pernambuco (UFPE). Email: junotcmatos@gmail.com.** Mestre em Filosofia pela Universidade Federal de Pernambuco (UFPE). E-mail: antoniobmad@gmail.com 
Aqui nos debruçamos com uma imensa dificuldade, visto que somos forçados e ser anti-nietzschianos na forma da escrita, porém nietzschianos em seu conteúdo. Mas são forma e conteúdo dissociáveis?

Acreditamos ser importante dizer isto, pois nossa análise nas próximas páginas estará centrada na Vontade de Poder: será ela, a Vontade de Poder compreendida como sendo a essência do mundo e da própria vida, o ponto de apoio metafísico ${ }^{1}$ dos quais os subsequentes conceitos serão consequência. Argumentaremos a razão de fazê-lo na próxima seção. A seção subsequente buscará responder à seguinte pergunta: o que Nietzsche entende por ideais ascéticos? Que características são essenciais a esse tipo de recusa do mundo, e como ele se relaciona à crítica nietzschiana da moral cristã? Por último buscaremos argumentar que o asceta, muito embora trave uma batalha contra a Vontade de Poder, não se configura como sendo um ente em que ela esteja ausente, pelo contrário: nesse sujeito a essência da vida existe, porém de maneira enfraquecida; o ascetismo é o sintoma do adoecimento da Vontade de Poder, não do seu desaparecimento.

\section{II - Vontade de Poder como mundo, Vontade de Poder como Vida}

Ao construir um texto acadêmico sobre a filosofia de Nietzsche acreditamos ser necessário construir um sistema, como já foi dito (fazer uma metafísica, em outras palavras). Escolheu-se por colocar a Vontade de Poder na base deste pequeno exercício metafísico porque esse conceito possui um papel de destaque se desejamos alcançar nosso objetivo. Ao argumentar que existe em Nietzsche certo darwinismo, apesar das críticas do filósofo ao biólogo inglês Charles Darwin, Constâncio (2010) nos fornece bons elementos para refletir sobre uma importante influência para Nietzsche na conceituação da Vontade de Poder. Ao descobrir que o ser humano, este ente tão deificado pela cultura contemporânea analisada por Nietzsche, não foi criado por deus algum, mas sim é produto do que o biólogo chama de evolução, Darwin, intencionalmente ou não, ajuda a fundar uma das bases para o questionamento da veracidade da doutrina cristã e de todo tipo de metafísica, religiosa ou não.

Mas a descoberta darwiniana vai além, pois segundo Constâncio "não há nenhuma característica da espécie humana [...] que transcenda a Natureza" (CONSTÂNCIO, 2010, p. 112). Reflitamos brevemente neste momento: se absolutamente todas as características humanas derivam da ordem natural (e não da ordem divina), que significa isto para as faculdades puramente humanas relacionadas à razão, por exemplo, e que nos diferenciam de todos os outros entes vivo? Pois ao observar empiricamente o mundo, ainda não se conseguiu encontrar outras vidas que fossem capazes de tais coisas, o que a priori poderia levar alguém a concluir ser o humano um ente parcial ou completamente independente da natureza, vivendo, portanto, fora dela e de suas leis, até mesmo chegando a perturbá-la.

Mas não é nesse sentido que a descoberta de Darwin aponta: em vez disso, a descoberta do cientista inglês nos faz compreender que o homo sapiens, integrante da natureza que é, e portanto sujeito que está às suas leis, é produto eternamente inacabado de um processo denominado seleção natural, que "estabelece assim, na adaptação e na vida que não é mais limitada, uma necessidade essencial de sobreviver" (AZEREDO, 2015 , p. 32). Isto é, nietzschianamente falando, temos a descoberta do ser humano, de toda vida e de tudo que existe no mundo como sendo produtos de uma intensa luta entre diferentes forças, uma constante afirmação de vidas que frequentemente cooperam entre si e se digladiam, bem como as constantes modificações na correlação dessas mesmas forças como sendo uma verdade absoluta sobre a existência.

Tudo isso leva Nietzsche a concluir que "toda força atuante, inequivocadamente" pode ser definida "como vontade de poder." (BM, § 36, p. 43). Mas se o próprio mundo - compreendido aqui como a totalidade de tudo que existe não foi criado por deus algum, e se ele não é algo acabado, mas sim um constante vir-a- 
ser, isso significa dizer que não faria sentido afirmar ser o mundo possuidor de um começo, ou mesmo de um fim. O mundo é o "começo" de si próprio (em verdade não seria possível falar em um "começo), já que ele não foi criado por alguma entidade divina habitante de um mundo "verdadeiro": "só há um mundo, e esse mundo é falso, cruel, contraditório, sedutor, sem sentido..." (KSA XIII, 11 (415), p. 177). O mundo é formado pelas forças que atuam nele; e se toda força é Vontade de Poder, logo o próprio mundo é Vontade de Poder. Vontade de Poder, por esse motivo, é a verdade absoluta e imutável que servirá de base para a metafísica que buscaremos montar no presente artigo, dadas as necessidades objetivas acadêmicas que se colocam no presente.

A Vontade de Poder, assim, é um conceito que esclarece qual é a essência do mundo, sua falta de começo e sua falta de um fim; pois se o real não foi "criado" por algo, logo, ele, em seu constante processo de vir-a-ser imanente, não caminha rumo a objetivo algum. Por isso podemos extrair a conclusão segundo a qual o mundo está em constante modificação em sua forma, sem no entanto se modificar em seu conteúdo essencial; esse é um motivo pelo qual não seria exatamente possível, a nosso ver, falar em uma "evolução das espécies" darwiniana no pensamento de Nietzsche.

Tendo nos debruçado sobre a Vontade de Poder como a essência do mundo, observemos agora como ela se expressa nas particulares dele habitante. Já havendo estabelecido que "a essência mais íntima do ser é vontade de poder" (KSA XIII, 14 (80), p. 235), é possível a partir disso concluir que os próprios entes, na medida em que derivam sua própria essência da essência do ser, também o são. Porém o ser é anterior ao ente, isto é: as infinitas atuações de força sobre força determinam o ser de todo ente, o que significa dizer que a Vontade de Poder determina a essência destes. Indo mais além: se todo ente, se toda força, é consequência de forças atuando sobre outras forças, logo o ente é determinado por algo que existe nele, mas não o é exatamente ${ }^{2}$ Para Nietzsche existiria algo, um "sentimento fisiológico básico" (CI, VI, § 6, p. 45), que determina todo ente, um afeto que impele as forças particulares a agir e buscar continuar sendo: esse afeto é também a Vontade de Poder; é ele que determina todos os outros, que por sua vez em conjunto determinam a racionalidade, no caso do ser humano.

Esse afeto fundamental é aquilo que determina toda vida a continuar vivendo, mas não no sentido de ser um "impulso de autoconservação" (BM, § 13, p. 20) spinozano (deixando claro que estamos falando da visão nietzschiana sobre Spinoza). Aqui estamos falando de um afeto que determina o sujeito a agir, apenas: constante e permanente expansão de sua essência e de sua força; ser mais para Nietzsche significa agir mais, não no sentido de alcançar um objetivo final (pois isso seria uma teleologia), mas sim no sentido de aumentar seu sentimento de poder ser, de maneira a expandir suas possibilidades de existência. Através do conceito Vontade de Poder, portanto, é possível compreender que para Nietzsche a vida não busca aumentar seu sentimento de prazer e diminuir seu sentimento de dor: pelo contrário, de maneira a alcançar determinados prazeres o sujeito precisa fazer um esforço para consegui-los, sendo este um processo também doloroso; ou seja, não se trata de buscar um e negar o outro, mas sim de buscar a expansão da própria essência, o que significa precisar aceitar sofrer e sentir prazer igualmente.

O conceito Vontade de Poder é, portanto, ao mesmo tempo uma defesa tanto do caráter múltiplo da vida e do ser humano em particular, como da maneira de ser forte em detrimento da maneira de ser fraca. Pois é a multiplicidade, a diversidade, que faz parte da própria essência de ser humano, fato este comprovado pelas constantes modificações de culturas e costumes ao longo da história de nossa espécie. É por essa razão que, para Nietzsche, o desejo dos chamados "moralistas" de "melhorar" o ser humano (ou seja: na prática torná-lo algo absolutamente coerente e uniforme) é tanto algo impossível, como algo indesejável: a "fascinante riqueza de tipos" (CI, V, § 6, p. 37) é justamente aquilo que faz o ser humano ser um ente tão interessante, e este é um dos caminhos através dos quais podemos compreender a crítica nietzschiana à noção de igualdade, compreendida como uma tentativa de apagamento das diversidades. E quem 
é o forte em Nietzsche, senão aquele que afirma sua própria essência, sem no entanto precisar negar a essência do outro? Isto é, estamos falando daquele sujeito que, como bom "imoralista" (segundo a moral cristã), compreende ser o humano em si múltiplo, como acabamos de expôr, e respeita essa multiplicidade, não possuindo, portanto, a necessidade do subjugar para se afirmar. $\mathrm{O}$ forte, nesse sentido, é aquele espírito livre capaz de poder ser mais exclusivamente a partir de si. Assim, diremos a partir de agora que este aspecto da Vontade de Poder se constitui como seu aspecto múltiplo, dado que a busca pela afirmação da multiplicidade de maneiras de ser existentes no mundo está no seu centro.

Mas a Vontade de Poder em Nietzsche, por outro lado, aponta também para outro caminho, a nosso ver inconciliável com o anterior: se todo ente busca expandir sua essência o máximo possível dentro do infinito caos de forças atuando sobre forças, é de certa forma lógico compreender que eventualmente alguma precisará subjugar a outra para se expandir. Até este ponto não acreditamos haver um problema, caso se decida por interpretar o aspecto anterior e o atual como se aplicando a todos os entes com a exceção do humano. Em outras palavras: para Nietzsche o engrandecimento do ser humano pressupõe a exploração do humano pelo próprio humano? Nas palavras do filósofo: "O apequenamento crescente do homem é precisamente a força impulsionadora para pensar no cultivo de uma raça mais forte" (KSA XII, 9 (153), p. 352). Ora, isso significa dizer que para o filólogo e filósofo a dominação de um grupo, ou grupos, de humanos por outros é condição para o engrandecimento destes últimos, que impondo sua Vontade de Poder sobre uma maioria conseguem com isso acumular um excesso de energia vital, que deverá se dirigir para campos mais nobres da existência, como é o caso das artes e da cultura em geral. A esse aspecto do conceito trabalhado nesta seção chamaremos aspecto unitário da Vontade de Poder, devido à tentativa perpetuada pelo forte de subjugar parte do mundo, no qual estaria inclusa uma maioria da humanidade, à sua essência: isto é, a Vontade de Poder do forte buscaria estar no centro de gravidade de uma unidade estabelecida entre si e as demais Vontades de Poder existentes no mundo.

A nosso ver, a Vontade de Poder nietzschiana defende coisas em si inconciliáveis: a plena autoafirmação do sujeito sem a necessidade de negar a diversidade humana é uma característica essencial do forte, mas ao mesmo tempo "sem o páthos da distância [...] também não tem como surgir de maneira alguma [...] aquela exigência por uma ampliação cada vez maior da distância no interior da própria alma" (KSA XII, 2 (13), p. 57). Quando se olha um lado do problema, a negação do outro para o engrandecimento de si deveria ser abominada pelo aspecto múltiplo da Vontade de Poder, por levar a um moralismo apagador das diferenças, enquanto que o outro lado revela ser a opressão de uns por outros uma infeliz necessidade, caso a humanidade deseje se libertar da moral gregária cristã.

\section{III - A MORAL ESCRAVA E O IDEAL ASCÉTiCo}

A terceira dissertação do livro "Genealogia da Moral", no qual se concentram a análise e crítica nietzschianas ao ascetismo, a nosso ver depende da apreensão de certos conceitos apresentados pelo autor. Compreendemos plenamente que afirmar tal coisa é controverso, pois seria, como já foi afirmado, pensar Nietzsche como um filósofo sistemático (algo que não era seu desejo), como se seu pensamento fosse como a construção de uma casa, na qual a correta compreensão desta depende da compreensão da disposição de seus tijolos. Mas argumentemos a nosso favor. $\mathrm{O}$ ascetismo, como buscaremos demonstrar aqui, se configura como uma reação do ser humano subjugado à condição de animal gregário contra essa mesma condição: sua cólera, entretanto, se direciona em parte contra si mesmo e em parte contra a ave de rapina que o esmaga. Assim, antes de nos debruçarmos sobre o ascetismo em si, definamos o que vem a ser esse humano reduzido a animal de rebanho de que Nietzsche fala e em cujo ser a nosso 
modesto ver se localiza a origem do ideal ascético, tal qual ele se apresenta na terceira dissertação de sua Genealogia.

Já na primeira dissertação desse livro o filósofo parece deixar clara qual a origem no Ocidente dessa maneira apequenada de ser humano: "os judeus, aquele povo de sacerdotes que soube desforrar-se de seus inimigos e conquistadores apenas através de uma radical tresvaloração dos valores deles"3 (GM, I, § 7, p. 26). Notemos aqui que o filósofo claramente fala em "conquistadores", isto é: analisando a história humana, Nietzsche percebe que houve um povo, ou povos, que conquistou, dominou, subjugou o povo judeu. Mas não sendo fortes o suficiente para enfrentar seus opressores de frente, restou a esse povo adotar uma estratégia distinta: fazer com que aqueles que eram outrora seus opressores, "o 'mundo inteiro', ou seja, todos os adversários de Israel, pudesse despreocupadamente" (GM, I, § 8, p. 27) abraçar a essência, o núcleo duro, da doutrina sacerdotal judaica e torná-la sua. Assim começa a lenta e gradual elevação da moral judaico-cristã (dado que, segundo Nietzsche, Cristianismo e Judaísmo possuiriam muito mais semelhanças do que diferenças) à condição de hegemonia no Ocidente: como um ato de vingança dos derrotados, dos que foram rebaixados à condição de ovelha à força pelos conquistadores animais de rapina; faltando àqueles força, restava lentamente converter seus outrora inimigos à sua causa. É nesse sentido que podemos, de maneira, nietzschiana, compreender a conversão do Império Romano ao Cristianismo: um povo que outrora abraçava valores aristocráticos eventualmente se rende à moralidade daqueles por eles outrora escravizados.

Isto é, da maneira como interpretamos o pensamento de Nietzsche, a origem da condição de fraco parece estar não apenas em sua falta de força, mas também na opressão do forte; um não existe sem o outro. ${ }^{4}$ E tanto era a opinião de Nietzsche que seria preciso travar uma guerra contra, oprimir, rebaixar uma parte da humanidade à condição de rebanho, de maneira a possibilitar a criação das condições sociais para o surgimento de uma classe nobre em todos os sentidos, inclusive e principalmente no sentido de ser seguidora e defensora da moralidade nobre nietzschiana (em si uma espécie de antimoral), que ele afirma explicitamente, a título de exemplo, ser o proposital despotismo direcionado contra a classe dos chandalas prescrito na Lei de Manu condição necessária para o "cultivo de uma determinada raça e espécie" (CI, VII, $\S 3$, p. 50) humana mais forte.

Isto é, aqueles que estudam Nietzsche sabem de suas opiniões contrárias à democracia e a noções tão caras à modernidade, como é o caso da igualdade. Compreendem também que sua crítica aos ideais ascéticos, sobre os quais nos debruçaremos agora, possui íntima relação com o que foi dito na sentença anterior, dadas suas origens plebeias e filo-cristãs (no caso do Ocidente). Porém acreditamos ser necessária a seguinte indagação: se Nietzsche se coloca como um defensor da moral nobre, e se o tipo nobre apenas pode existir não apenas pela plena autoafirmação deste, mas também pelo proposital rebaixamento do fraco, em certa medida não serviria um conceito como o ideal ascético, típico do modo de valoração escravo, como mecanismo de controle social imposto sobre a base da pirâmide social para cultivar "determinada raça e espécie" (Idem) nobre? Não possuiria a crítica nietzschiana ao ascetismo seus limites, servindo os propósitos políticos do filósofo até certo ponto? Este será um dos pontos de apoio de nossa argumentação sobre a visão nietzschiana acerca do ascetismo.

Que são, portanto, os ideais ascéticos? Concordamos com a interpretação de Corrêa ao afirmar que o ascetismo para Nietzsche é, simplificadamente, uma tentativa de "auto aniquilamento de si, isto é, da vontade entendida como a pulsação vital." (CORREAA, 2016, p. 123). O ascetismo se constitui como uma forma de violência do ser humano contra si próprio, ou melhor: uma prática violenta direcionada contra uma face de si, pois para Nietzsche parece existir no ser humano uma pulsão por navegar em terrenos tidos pela moralidade do costume como perigosos. Tanto assim o é que, segundo o filósofo, se na contemporaneidade tudo aquilo relacionado ao mundo dos afetos mais íntimos, como a sensualidade, o sexo, a violência, a crueldade, dentre outros prazeres mundanos reflexo das contradições inerentes ao ser humano, são objeto 
de proibição e são condenados pela moral cristã vigente, no passado o contrário teria sido verdadeiro. Para ele tudo aquilo que em tempos contemporâneos é cercado por barreiras, restrições e ameaças de castigo possuiu "durante muito tempo a consciência do seu lado" (GM, III, § 9, p. 102). Isto é, no passado teria sido objeto de vergonha, restrição e punição justamente o perdão, a compaixão e a benevolência, pois para

34 Nietzsche o processo civilizatório de certa forma domestica o outrora animal humano numa tentativa de "melhorá-lo". Assim, o que antes se localizava no nível da consciência passa ao nível do desejo inconsciente e vice-versa. Isso significa dizer que essa análise do filósofo oriundo de Röcken abre espaço para interpretarmos que existe uma pulsão pelo proibido no humano, e que de certa forma faz parte de sua essência. Nesse sentido, nos colocamos diante de um paradoxo: ao passo que a renúncia daquele mundo no qual os desejos mais íntimos habitam, típica, por exemplo, da prática filosófica, teria sido condição necessária para o surgimento de algo tão nefasto como o ascetismo tal qual Nietzsche compreende como sendo típico da contemporaneidade, também a teria sido para "o pouco de razão humana e de sentimento de liberdade que agora constitui nosso orgulho" (A, $\S 17$, p. 25). Isto é, é a busca pelo proibido, essencial ao ser humano, que torna-o um ente tão interessante e profundo, pois se por um lado prepara o terreno para o arrebanhamento da humanidade, por outro também funda as bases para a morte de Deus involuntariamente perpetrada pela modernidade dominada pelo modo de ser metafísico. As constantes condenações do mundo da vida pelo Cristianismo e o constante subjugamento da humanidade pela noção de igualdade gregária apenas servem de combustível para impelir o ser humano no sentido contrário: talvez nesse sentido possamos compreender o anúncio feito por Zaratustra da redenção da humanidade pela via do Além-do-Homem.

E já que chegamos à discussão sobre Deus e a crítica nietzschiana à metafísica, é exatamente nessas noções que se baseia o ascetismo no Ocidente. Para Nietzsche o sacerdote ascético estabelece valores para a vida terrena (segundo o filósofo, a única vida que existe) a partir de "uma existência inteiramente outra" (GM, III, § 11, p. 106). Isto é, esse sacerdote estabelece essa outra existência (para Nietzsche fictícia), ideal, divina, como uma verdade absoluta e julga o mundo que para o filósofo é verdadeiro a partir dela. Ou seja, o que percebemos aqui é haver na prática uma negação do mundo material e de tudo que a ele pertence (os prazeres da carne, assim como o afeto do ódio), o que em verdade se configura como uma negação da vida mesma. $\mathrm{O}$ asceta possui repulsa pelo viver, e assim o sendo, busca ao máximo fazer desta existência um torturante caminho a ser traçado para chegar a essa outra vida e nela ser um forte. $\mathrm{E}$ nesse sentido que interpretamos a martirização de si, a culpa, o ressentimento e a castidade cristãos criticados por Nietzsche: como uma busca por torturar a si ao máximo, pois segundo essa doutrina, quanto mais se sofre no mundo material, em melhor posição se estará no mundo dito "real", já que a negação daquele é uma afirmação deste. O Cristianismo, tal qual o Judaísmo, inverte a moral nobre e transforma em fortes os fracos, o que para Nietzsche é algo absurdo.

Dessa forma, o ideal ascético possui como outra importante característica o desejo por morrer, pois estamos falando de uma forma de vida que, ao mesmo tempo que vive, paradoxalmente afirma travar uma guerra contra a própria vida: "aqui se faz a tentativa de usar a força para estancar a fonte da força" (Idem, p. 107), e é por isso que se faz necessária a vida de autopunição exercida pelo casto cristão, quando o desejo por exercer a sexualidade continua cada vez mais e mais forte, dado o acúmulo energético devido à sua não-satisfação. Sendo assim, faz-se necessário perguntar: por que, então, o asceta não decide pelo caminho da negação prática e total da vida (em uma palavra, suicídio), ao invés de viver uma vida de eterno suplício?

A resposta que Nietzsche nos dá a essa indagação é bastante interessante e curiosa: não é que o ideal ascético em termos práticos trave uma guerra contra a vida; de certa forma tal coisa é verdade, mas isso se configura como mais discurso asceta do que sua prática. Para nós é algo claro que o ascetismo possui ódio pela vida, visto que ela é Vontade de Poder, e é esta que serve de instrumento de esmagamento do fraco pelo 
forte; isso discutiremos com maior profundidade na próxima seção. Porém o que Nietzsche nos mostra é ser o ideal ascético na prática uma afirmação de determinado tipo de vida: o ascetismo serve como instrumento de "cura e proteção de uma vida que degenera" (Idem). Percebamos, portanto, algo interessante: a princípio poderíamos pensar, dado tudo que foi exposto, que o ascetismo possui um aspecto puramente negativo, de negação prática pura e simples da vida mesma, dado que aquele plano extraterreno é uma ficção; mas não é essa a verdade. Na realidade o ideal ascético é consequência da afirmação de um determinado tipo de existência; um tal que, por ser vida, trava uma intensa luta por afirmar sua Vontade de Poder no mundo, e assim continuar vivendo. Uma vida miserável, doentia, domesticada, que sendo fraca em energia vital para derrotar seus opressores, busca a todo custo uma justificativa, um culpado pela sua desgraça, e encontra, através do sacerdote, uma narrativa convincente: o culpado por essa situação de sofrimento é o próprio sofredor. $\mathrm{O}$ ascetismo é, portanto, um sintoma dessa falta de força para reagir, sendo esta a doença. Poderíamos, inclusive, caracterizar essa doença de outra forma: como um achatamento da Vontade de Poder.

\section{IV - Ascetismo como sintoma: a Vontade de Poder adoentada}

Como já foi exposto, segundo Nietzsche o mundo é um conjunto caótico de infinitas forças, por vezes cooperando e por vezes travando uma guerra entre si: cada uma dessas forças, por sua vez, pode ser definida como Vontade de Poder, e busca, tanto quanto possível, expandir sua essência. Isto é, a Vontade de Poder não busca a conservação de si própria, mas sim agir cada vez mais. Expusemos anteriormente que a vida ascética precisa ser protegida, então a propósito disso sentimos necessário fazer uma breve reflexão. Segundo nossa interpretação de Nietzsche, a vida que precisa ser protegida, que deseja se autoconservar ao invés de sair de sua zona de conforto, se configura como uma vida fraca. Pois já que não é forte o suficiente para afirmar sua essência com a máxima plenitude, busca refúgio naquilo que é mais confortável: o mero esforço por continuar vivendo. Assim, faz-se necessário colocar a questão: apenas continuar vivendo já é o bastante? Para o asceta a maneira como se vive não importa? Se sim, então isso poderia ser encarado como confirmação da mediocridade que existe por trás do desejo de conservar a si que existe no ideal ascético, ao invés de agir para expandir a Vontade de Poder ao máximo. Por outro lado, também se poderia interpretar que a Vontade de Poder ascética de fato se expande, embora se dirija não para fora de si, para o mundo, mas si para dentro e contra si própria. Tanto assim o é, que com a tentativa de "melhora" do ser humano feita pelo sacerdote do ascetismo, "a condição enferma expandiu-se e aprofundou-se com espantosa rapidez" (GM, III, § 21, p. 131). E não poderia ter resultado em outra coisa, pois a moral escrava busca combater o ser humano em sua realidade ao invés de aceitá-lo em suas contradições, numa tentativa de torná-lo algo que ele não é.

Assim, não acreditamos ser correto afirmar que o asceta seja um ente desprovido de Vontade de Poder, pois o próprio mundo o é, o que significa dizer que absolutamente toda vida (tenha ela prazer de viver ou não), inclusive a vida ascética, é Vontade de Poder. O sentido para o qual se direciona sua força já o sabemos: para dentro, contra si própria, buscando a autoanulação, embora na prática afirme a si como apequenada; pois a razão fornecida pelo sacerdote trilha o caminho da redenção no além pelo sentimento de culpa (dentre outros) na materialidade, ao invés da redenção na imanência pela ação. $\mathrm{O}$ ideal ascético existe, portanto, como uma maneira de dar sentido a uma vida que sofre. Mas de onde provém seu sofrimento? Aqui retornamos a uma polêmica já levantada por nós: o desejo de morte da vida escrava que acha seu conforto no ascetismo provém de um dos aspectos da Vontade de Poder já apontado por nós, este compreendido não apenas como exercício de poder sobre o mundo (pois exercer poder sobre o mundo é, a nosso ver, algo inevitável), mas mais do que isso: como exercício de poder autoritário e predatório do ser humano sobre outros seres humanos ${ }^{5}$. Para nós não 
é possível ignorar que, ao mesmo tempo que existem ferramentas teóricas em Nietzsche muito interessantes para pensarmos a emancipação humana, também existe uma concepção elitista de sociedade que não pode ser ignorada.

E qual a razão dessa concepção elitista? Uma delas, como já foi apontado por nós, é o fato de Nietzsche acreditar ser preciso que a humanidade se emancipe de sua condição gregária cristã através do pleno exercício de sua Vontade de Poder. Mas para o indivíduo humano conseguir expandir sua essência ao máximo é necessário não apenas exercer poder sobre os entes não-humanos, mas também sobre os humanos, dado que uma maioria deve trabalhar para gerar um excedente de energia vital numa casta dominante, assim gerando como consequência, terrível apesar de necessária, uma população que viveria nas mais miseráveis condições de vida possíveis: "epidemias assassinas, horríveis doenças venéreas e, depois, novamente a 'lei da faca', prescrevendo a circuncisão dos meninos e a remoção dos pequenos lábios das meninas" (CI, VII, § 3, p. 51); é essa a consequência do pleno exercício de Vontade de Poder segundo seu aspecto unitário, e que da maneira que Nietzsche conceitua se configura na prática como algo predatório e escravizante. Os termos "querer-dominar" (GM, I, $\S 13$, p. 36) e "querer-subjugar" (Idem), utilizados por ele ao se referir à relação entre a ave de rapina e a ovelha, a nosso ver são expressões que, dentre outras coisas, defendem um determinado tipo de relação social muito concreto que deve existir entre humanos. Dessa maneira, a palavra "humanidade", utilizada aqui neste parágrafo, na prática não se referiria ao conjunto dos seres humanos tomados em igualdade, pois esta é uma concepção cristã: "humanidade", no sentido mais pleno de Vontade de Poder à luz de seu aspecto unitário (pois à luz do aspecto múltiplo a consequência prática deve ser a noção oposta a esta), portanto, se referiria a uma elite dominante. Tanto assim o é, que Nietzsche deixa claro que para ele "toda elevação do tipo homem foi obra de uma sociedade aristocrática [...] que tinha necessidade de escravidão" (KSA XII, 2 (13), p. $57)$.

Tomando tudo que foi escrito até este momento em conta, consideramos que o ascetismo cumpre um papel de controle social muito importante, pois tanto melhor para as castas nobres se os membros das castas subalternas colocarem suas Vontades de Poder contra si próprias, assim buscando permanecer escravos e fracos, já que a estes estaria reservado o reino dos céus. E para reforçar ainda mais esta perspectiva, além de novamente sugerir a leitura da seção de "Crepúsculo dos Ídolos" em que Nietzsche analisa a "Lei de Manu" (CI, VII, § 3), ainda ressaltamos que em certo aforismo de "Humano, Demasiado Humano I" o filósofo analisa a relação entre religião e governo de tal forma, que não apenas se configura como uma investigação realista, mas também a nosso ver complementa sua análise elogiosa de Manu, utilizada como exemplo prático de cultivo de uma raça forte, e do papel do sacerdote ascético em "Genealogia da Moral". Para Nietzsche "o Estado sabe conquistar os sacerdotes, porque tem necessidade de sua privatíssima, oculta educação das almas” (HDH I, § 472, p. 252). Ora, mas quem detém o poder de Estado senão a casta dominante, e em que consiste a "educação das almas" promovida pelo sacerdote, senão numa domesticação do ser humano, isto é, uma tentativa de forcá-lo à condição de animal gregário? É possível aqui perceber que a crítica nietzschiana à redução da humanidade a um rebanho de ovelhas possui seus limites. Pois se por um lado o rebaixamento de todos os humanos pela moral cristã e pela democracia é objeto de sua repulsa, por outro o rebaixamento de uma maioria em prol do engrandecimento da Vontade de Poder de uma minoria forte serve perfeitamente aos propósitos do aspecto unitário da Vontade de Poder.

E é a Vontade de Poder mesma o objeto de ódio da maioria gregária segundo o filósofo, pois é na relação de forças atuando sobre outras forças que a ovelha perde para o animal de rapina. Que resta então, senão a ovelha travar uma guerra contra a Vontade de Poder? Mas se a Vontade de Poder constitui o ser também da própria ovelha, logo lutar contra a Vontade de Poder significa lutar contra si. Isto é, o ascetismo é sintoma de uma vida, de uma Vontade de Poder, que está doente, e tanto assim está, que deseja a libertação pela morte (pois anseia um mundo que não este) e trava uma luta contra si 
própria. Pois se o saudável é a Vontade de Poder lutar para se afirmar, o sintoma do adoecimento da Vontade de Poder apenas pode ser um lutar para negar a si. Ironicamente, isso até certo ponto serve aos propósitos do forte, como já expusemos, pois o forte necessita do fraco para que exista um excesso de energia vital naquele em detrimento deste. Se dessa maneira as coisas tivessem continuado, é possível que os ideais ascéticos fossem menos um objeto de crítica e mais um objeto de elogio por Nietzsche. Mas não foi assim que ocorreu, pois claramente a declaração nietzschiana "Que os doentes não tornem os sadios doentes" (GM III, § 14, p. 114) não foi seguida pelo Ocidente. $\mathrm{O}$ ascetismo se torna um problema, segundo nossa interpretação de Nietzsche, quando os fortes e felizes começam "a duvidar assim do seu direito à felicidade." (Idem) Lembremos que a vitória da moral judaica contra a moral aristocrática, característica dos seus contemporâneos romanos, por exemplo, não se deu no curto, mas a longo prazo: primeiro com a criação do Cristianismo (que para ele prega a mesma moral que o Judaísmo), depois com a cristianização do Império Romano, o crescente fortalecimento dessa moral através da ocidentalização do mundo, até por fim chegar à modernidade com, por exemplo, a democracia. É em sua contemporaneidade que Nietzsche percebe residir o grande perigo, visto que é também a própria classe dominante, outrora guiada por valores aristocráticos, que agora nesse novo momento está em defesa dos valores democráticos plebeus, e portanto do lado da trincheira dos que travam guerra contra a Vontade de Poder.

\section{V - CONSIDERAÇÕES FINAIS}

Em suma, segundo nossa interpretação, o problema para Nietzsche não é o ascetismo, visto que até certo ponto ele poderia servi-lo. O problema é a moral judaicocristã que é sua base, tornando aquele regra geral, assim consumando a vitória na modernidade de uma moral outrora perdedora na antiguidade. Como forma de combater esse adoecimento geral, Nietzsche propõe um retorno a uma moral aristocrática pela via da Vontade de Poder, muito embora a nosso ver ele não consiga resolver o problema de decidir pela via da unidade ou pela via da multiplicidade desse conceito. Pois se o primeiro aspecto aponta para um novo tipo de moralismo e apagamento das diversidades através da imposição da vontade do forte sobre uma maioria, o segundo necessita que haja uma noção de igualdade mínima entre as diversas maneiras de ser socialmente compartilhada pela humanidade, de maneira a contemplar a "fascinante riqueza de tipos" (CI, V, $\S 6$, p. 37) tão elogiada por ele repetidas vezes em seus escritos, e que sempre foi combustível para suas críticas ao Cristianismo.

\section{REFERÊNCIAS}

AZEREDO, Jéferson L. Os sentidos e consequências do darwinismo nas obras de Nietzsche: seleção natural e poder como fundamentos à vida. In: Revista Lampejo - Revista eletrônica de filosofia e cultura, vol. 1, n. 8, pp. 29-50. Fortaleza, 2015.

CONSTÂNCIO, João. Darwin, Nietzsche e as consequências do darwinismo. In: Cadernos Nietzsche, n. 26, pp. 109-154, 2010.

CORRÊA, Sergio Fernando Maciel. O niilismo e os ideais ascéticos na terceira dissertação da Genealogia da Moral. In: Saberes - Revista interdisciplinar de filosofia e educação, vol. 1, n. 13, Março, pp. 120-133. Natal, 2016.

NIETZSCHE, Friedrich. Além do Bem e do Mal. (Tradução de Paulo César de Souza). São Paulo: Companhia das Letras, 1992.

NIETZSCHE, Friedrich. Aurora. (Tradução de Paulo César de Souza). São Paulo: Companhia das Letras, 2004.

NIETZSCHE, Friedrich. Crepúsculo dos Ídolos. (Tradução de Paulo César de Souza). São Paulo: Companhia das Letras, 2006. 
NIETZSCHE, Friedrich. Fragmentos Póstumos 1885-1887. (Tradução de Marcos Antônio Casanova). Rio de Janeiro: Forense Universitária, 2013.

NIETZSCHE, Friedrich. Fragmentos Póstumos 1887-1889. (Tradução de Marcos Antônio Casanova). Rio de Janeiro: Forense Universitária, 2012.

NIETZSCHE, Friedrich. Genealogia da Moral. (Tradução de Paulo César de Souza). São Paulo: Companhia das Letras, 1998.

NIETZSCHE, Friedrich. Humano, Demasiado Humano I. (Tradução de Paulo César de Souza). São Paulo: Companhia das Letras, 2000.

\section{Notas}

1 Pois se aqui escreveremos sistematicamente, logo, segundo a filosofia nietzschiana, estaríamos fazendo uma metafísica.

2 Não o é, pelo menos não no sentido de ser um "sujeito" racional compreendido como um ente que conhece um "objeto" a ele exterior. Essa divisão entre sujeito e objeto, por sinal, é bastante criticada pelo filósofo aqui trabalhado.

3 Há um grande debate no meio acadêmico se as opiniões emitidas por Nietzsche sobre o povo judeu possuiriam um caráter antissemita. Não é nosso objetivo nos debruçar sobre este assunto neste momento, porém acreditamos não ser importante deixar claro ser a postura deste que escreve contra toda forma de racismo, o antissemitismo incluso. Aqui estamos apenas buscando apresentar partes do pensamento de Nietzsche, bem como nossa humilde interpretação crítica sobre ele.

4 Possuímos noção que essa é uma interpretação suscitadora de polêmicas, dado que ressaltaria aspectos politicamente autoritários do filósofo. Pois já que em outros escritos Nietzsche dá margem à leitura contrária, havendo, portanto, outras interpretações sobre o mesmo assunto (pelas quais nutrimos enorme respeito), este é mais um motivo pelo qual acreditamos ser difícil estabelecer uma coerência sistemática em seu pensamento. Entretanto, se faz necessário abraçar a sistematicidade neste momento, o que significa que é preciso escolher uma interpretação acerca do assunto e se manter fiel a ela.

5 Reconhecemos que, por outro lado, Nietzsche também concebe a Vontade de Poder de tal forma que ela contraditoriamente aponta para a afirmação da multiplicidade de maneiras de ser humano, reforçada pela posição antimoralista do filósofo. Não acreditamos ser necessário nos alongar neste ponto, porém já que neste momento estamos adentrando mais a fundo a filosofia política do autor, acreditamos ser necessário deixar clara nossa opinião. Em termos práticos, acreditamos que a Vontade de Poder concebida desta forma precisaria apontar para um sistema político onde pelo menos o mínimo de igualdade social e política fosse regra, pois do contrário, como seria possível incentivar e abarcar a diversidade humana numa sociedade? Isso a nosso ver contrasta enormemente, quando tratada em termos práticos, isto é, no fazer político concreto e não na mera abstração teórica, com aquele outro aspecto da Vontade de Poder. 